\title{
WOMEN AND ISIS LOCHIA: COMMEMORATIONS OF DIVINE PROTECTION IN ROMAN MACEDONIA* \\ Mujeres E Isis LoChia: CONMEMORACIONES DE LA PROTECCIÓN DIVINA EN MACEDONIA ROMANA
}

\author{
DafNi Maikidou-Poutrino \\ Aristotle University of Thessaloniki \\ MAIKIDOU@HIST.AUTH.GR
}

\begin{abstract}
In four cities of Roman MacedoniaThessalonica, Dion, Beroea and Stobi- six dedicatory inscriptions testify to the presence of Isis Lochia, a deity who protected women at childbirth. These dedications, made both by men and women, commemorate the gratitude to a goddess who safeguarded the precarious passage from pregnancy to motherhood. The present research brings these data together in order to gain insights in the public expression of this religious activity. The information furnished by the inscriptions and the votive reliefs, the place of the dedications inside or outside the temple, the location of the temple in relation to the urban grid, the social status of the social actors, they all contribute to
\end{abstract}

\begin{abstract}
RESUMEN
Las inscripciones con dedicatoria de cuatro ciudades de la Macedonia romana -Thessalonica, Dion, Beroea y Stobi- dan cuenta de la presencia de Isis Lochia, una divinidad que protegía a las mujeres en el parto. Dichas dedicatorias, realizadas tanto por hombres como mujeres, expresan su gratitud a una Diosa que guiaba el paso del embarazo a la maternidad. El presente estudio reúne esta información con el objetivo de aproximarse en profundidad en la expresión pública de esta práctica religiosa. Los datos aportados por los relieves votivos y las inscripciones, por el lugar de las consagraciones dentro y fuera del templo, la localización del templo en relación al entramado urbano y el estatus social de los actores so-
\end{abstract}

\footnotetext{
* This paper was presented in the doctoral conference "Women and the construction of Religious Memory in Antiquity" held in the Universidad Carlos III de Madrid on May 16 ${ }^{\text {th }}$, 2018. I am grateful to J. Alvar Ezquerra, V. Gasparini and G. Woolf for their comments and suggestions on my research. In addition, I would like to thank my supervisor of the Aristotle University of Thessaloniki, E. Voutiras, for his suggestions and fruitful conversations on the subject.
} 
the reconstruction of religious memory as shaped by the relationship between women and Isis Lochia. In addition, these acts are explored as components of cultic activities that had a noteworthy continuity through space and time in ancient Greece. ciales contribuyen a la reconstrucción de la memoria religiosa tal y como la proyectó la relación entre las mujeres e Isis Lochia. Estas practicas son además exploradas como parte de actividades de culto que tuvieron una continuidad reseñable en el espacio y el tiempo de la Grecia Antigua.

\section{KeYWORDS}

Isis Lochia; Macedonia; women; childbirth; protection; inscriptions

\section{Palabras Clave}

Isis Lochia; Macedonia; mujeres; parto; protección; inscriptiones

Fecha de recepción: 06/10/2018

Fecha de aceptación: 18/02/2019 


\section{INTRODUCTION}

In the Hellenistic and Roman periods, the worship of the Egyptian deities spread from their native land across the Mediterranean reaching important ports as well as inland cities. ${ }^{1}$ Macedonia was a region where already from Hellenistic times the Isiac deities prospered due to the commercial maritime routes. ${ }^{2}$ While the Egyptian deities had already reached Macedonia, the Roman conquest and the creation of Roman colonies ${ }^{3}$ was an important factor for the addition of the Isiac gods to a dense network in which ideas and religious practices travelled. The spread of their cult by land was also benefited by via Egnatia, the military road that connected the Adriatic Sea with the Hellespont. It is noteworthy that the cities on via Egnatia had a strong Isiac presence. ${ }^{4}$

1. On the expansion of the cult through the Aegean and the Isiac presence in each different site see for example Dunand, 1973b; Wild, 1984; and Bricault, 2001. For the reasons of the diffusion see also Versnel, 1990, pp. 39-41.

2. For the expansion of the cult in Greece see Dunand, 1973b. For the different sites of Macedonia see also Bricault, 2001, pp. 22-27.

3. Evidence of the Isiac cults has been confirmed in at least two Roman colonies of Macedonia. On Colonia Iulia Augusta Diensis, see Pandermalis, 1982 and on Colonia Iulia Augusta Philippensis, see Collart, 1929.

4. See Heraclea, Thessalonica, Amphipolis and Philippi in Bricault, 2001, pp. 22-27. 
Isis was a goddess with great adaptability, given a plethora of different attributes, and connected with different activities. ${ }^{5}$ In particular, her association with women is of great interest even from pre-Greco-Roman Egypt where she was venerated as a mother goddess along with her son, Horus. ${ }^{6}$ This identity of Isis spread throughout the Mediterranean. Several Hellenistic aretalogies identify her as a women's goddess. "I am she who is called goddess by women" proclaims an aretalogy of the $2^{\text {nd }}$ or $3^{\text {rd }}$ century AD from Kyme in western Asia Minor. Through the aretalogies, ${ }^{8}$ it is understandable that Isis offered to women multiple reasons for seeking her protection.

Women worshipped Isis as she was the goddess that followed them through the fragile periods of life and filled their emotional needs that went unheeded in other cultic activities in the Greek and Roman world. Isis, in her relations with Osiris and Horus, had experienced the joy of marriage and motherhood and the grief of death and separation. Thus, she had experienced important transitional periods that comprised the life of ancient women. ${ }^{9}$ Moreover, her reactions and her emotions such as love, loyalty, sorrow, and compassion, were very familiar to women. ${ }^{10}$ For all these reasons, she provided a female figure with whom they could truly identify.

Particularly in Macedonia, Isis was also venerated under a very specific form, the one of Isis Lochia, protector of childbirth. The public expression of the cult of Isis Lochia, a deity connected with pregnancy and motherhood, created a vivid image of the deity, involving both men and women in her veneration and, at the same time, creating connections with other divine figures as well. The cult of Isis Lochia has survived through testimonies from both sanctuaries and public space of the Macedonian cities.

Outside Macedonia the presence of Isis as Lochia has been suggested only in one papyrus text from Egypt ${ }^{11}$ while her existence in Egypt and especially in Alexandria is debatable. ${ }^{12}$ Nevertheless, the worship of Isis as a goddess of labour

5. On the different names of the goddess see Bricault and Dionysopoulou, 2016.

6. Kraemer, 1992, p. 71.

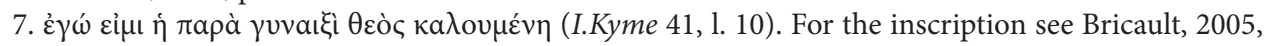
pp. $422-425, \mathrm{n}^{\circ} 302 / 0204$.

8. See the aretalogies in Heyob, 1975, pp. 46-49.

9. Kraemer, 1992, p. 74.

10. Heyob, 1975, p. 44.

11. Bricault and Dionysopoulou, 2016, 40 referring to P.Oxy. XI 1380, 27. In Grenfell and Hunt, 1915, p. 196, though, it is suggested to read $\lambda o[\gamma\llcorner\sigma \tau \iota \kappa \eta \dot{v}]$ instead of $\lambda$ oxía.

12. The presence of a temple of Isis in the cape Lochias has caused a debate among the researchers. See for example Dunand, 1973a, p. 111 but see also Coche de la Ferte, 1975, p. 282; Bricault, 2006, pp. 121-122; Malaise, 2005, p. 150; Malaise, 2007, p. 32. New excavations revealed a monolithic pylon 
was widespread among the Romans. ${ }^{13}$ Ovidius, in one of his elegies, ${ }^{14}$ prays to Isis in order to save his beloved Corinna after an abortion. The aretalogies also give valuable information about the relation of the goddess with childbearing and the institution of parenthood. ${ }^{15}$

Birth is a natural process which in ancient and Roman Greece was handled almost exclusively by women but it is also a social event. Subsequently, midwives, birthing assistants and mothers would be involved in this procedure. At the same time, they would need a deity to safeguard this difficult passage. ${ }^{16}$ Isis Lochia is not the first deity who was part of this experience. The Egyptians had several deities protecting this transitional phase such as Bubastis, ${ }^{17}$ Hathor ${ }^{18}$ or Bes. ${ }^{19}$ The reasons why Isis also serves this same role are multifold. She was a goddess that represented a mature sexuality. She was a deity that had been a sister, a wife and a mother. As a result, she had experienced the anxiety and the dangers of childbirth and she could safely guide the parturient through this process.

around the cape Lochias of Alexandria highlighting the existence of a temple. On these new findings see Savvopoulos, 2010, p. 86.

13. See also Dunand, 1962.

14. Ovid, Amores II 13, 7-22: Isi, Paraetonium genialiaque arva Canopi / quae colis et Memphin palmiferamque Pharon, I quaque celer Nilus lato delapsus in alveo / per septem portus in maris exit aquas, I per tua sistra precor, per Anubidis ora verendi / sic tua sacra pius semper Osiris amet, / pigraque labatur circa donaria serpens, / et comes in pompa corniger Apis eat! / huc adhibe vultus, et in una parce duobus! I nam vitam dominae tu dabis, illa mihi. / saepe tibi sedit certis operata diebus, / qua cingit laurus Gallica turma tuas. / Tuque laborantes utero miserata puellas, / quarum tarda latens corpora tendit onus, / lenis ades precibusque meis fave, Ilithyia! Translation by Showerman, 1914, pp. 421-423: "Isis, thou who in Parætonium dost dwell, and in Canopus' kindly meads and Memphis and palm-bearing Pharos and those plains where the Nile, quitting its mighty bed, flows and bears through seven channels its hurrying waters to the sea. By thy timbrels I entreat thee, and by the head of dread Anubis--so may the pious Osiris ever accept thy offerings, so may the drowsy serpent glide round about thine altars, and the hornèd Apis march in the procession; look mercifully on Corinna, and spare two lives in one, for thou to my mistress wilt give life; she will give life to me. Full often, on days appointed for thy worship, hath she sat within thy temple at the hour when thy priests enwreathe their brows with laurel. And thou who takest pity on women who are suffering the pangs of childbirth when they seek to be delivered of the burden that stirs within them, come, propitious Ilithyia, and hearken to my prayers".

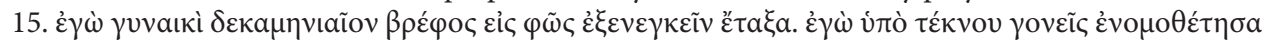

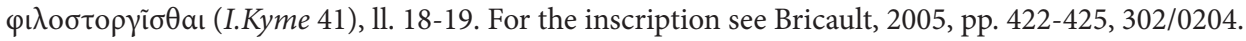

16. Hänninen, 2005, p. 49.

17. Dunand, 1979, p. 32; Dunand, 2013, p. 212; Malaise, 2007, p. 24.

18. Hart, 2005, p. 64.

19. Hart, 2005, p. 49. 
The Greeks had different deities protecting childbirth as well. Eileithyia ${ }^{20}$ was one of these goddesses, known since the time of the Homeric poems. ${ }^{21}$ Her name means literally "she who comes". Eileithyia, as well as other birth deities, were the ideal personification of a safe and quick delivery. They were invoked by the woman giving birth or her assistants and they were conceptualised as midwives. ${ }^{22}$ Eileithyia was often associated with other deities, such as Artemis. It has been maintained that women would invoke Artemis in order to conciliate her retrospectively for the loss of their virginity. In addition, she was a deity that followed the lives of women since they were children ${ }^{23}$ looking after them through the transitional states of their lives, from childhood to puberty. ${ }^{24}$ They served her in puberty rites $^{25}$ and dedicated their toys, their clothes and their hair to her when they would get married. ${ }^{26}$ Artemis was invoked during childbirth with a plethora of different names, such as Artemis Soodina, Praiai, Hemere, Lochia, Eulochia, Eileithyia, Genetaira, Lusizonos. ${ }^{27}$ It should not be overlooked that Artemis was closely associated with Iphigeneia whose name has been explained literally as "strong in birth". Other deities considered to help during childbirth were also Hera, Hekate, the Erinyes, the Moirai and the Nymphs. ${ }^{28}$

It was not just an easy birth for which the pregnant women prayed. It was at least equally important to deliver an offspring healthy and well-formed..$^{29}$ Moreover, they needed someone to determine the length of the pregnancy. ${ }^{30}$ Consequently, the role of birth deities was not just limited to assisting in labour but referred to everything that happened before, during and after birth. As a result, they cared about the procreation and the blessing of children. They took care of the woman and the newborn and they had healing properties in case of complications.

20. On Eileithyia see Pingiatoglou, 1981.

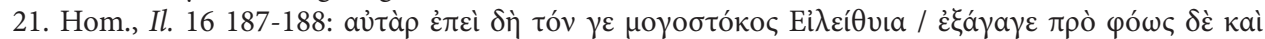

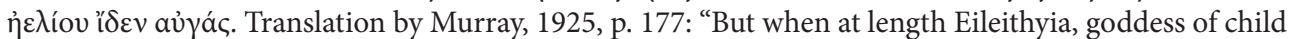
birth, had brought him to the light and he saw the rays of the sun".

22. Garland, 1990, pp. 66-67.

23. On Artemis and the rituals of girls before and after childbirth see Cole, 2004, pp. 210-212.

24. Bruit-Zaidman, 1996, p. 34

25. Demand, 1944, p. 88.

26. Morizot, 2010, pp. 467-468. See for example the case of Timareta, described in Bruit-Zaidman, 1996, p. 34 and Brulé, 1996, pp. 12-13.

27. Cole, 2004, p. 212 and Morizot, 2010, p. 465.

28. Garland, 1990, p. 67; Mehl, 2009, p. 194; Morizot, 2010, pp. 464-465. Hänninen, 2005, p. 50 refers to no less than fifty-eight deities related to birth in the Roman world.

29. Garland, 1990, p. 68.

30. Hänninen, 2005, p. 51. 


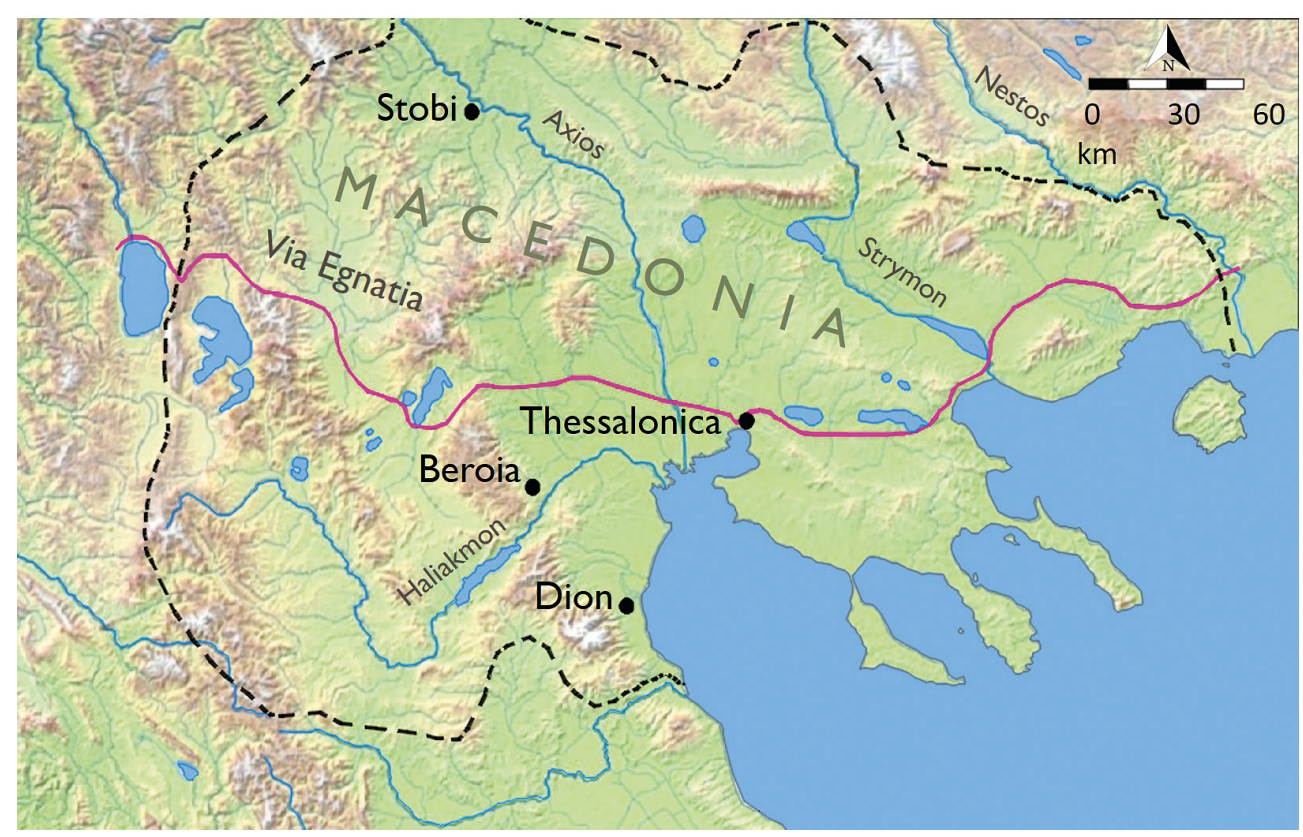

Image 1. Macedonian cities with the presence of Isis Lochia.

The aforementioned relation between the protecting deity and women is materialised in the following case studies. The evidence taken into account in order to identify the presence of Isis Lochia at a site are the inscriptions which still preserve the name of the goddess. Other artefacts supporting the veneration of Isis Lochia are scarce; only some reliefs play a secondary role in enforcing her presence. Her name has survived in six inscriptions which come from four different Macedonian cities, Thessalonica, Beroea, Stobi and Dion (image 1).

\section{THESSALONICA}

The first dedication comes from Thessalonica. The sanctuary of the Isiac deities in the city existed since the $3^{\text {rd }}$ century $\mathrm{BC}$ and it was of noteworthy importance. It was situated within the city walls, near the western city gate and the harbour. ${ }^{31}$ One of the

31. On the sanctuary see Makaronas, 1940, pp. 464-465 and Steimle, 2008, pp. 79-131. 
seventy-eight inscriptions ${ }^{32}$ found in the sanctuary and the surrounding area mentions the presence of a cella and of altars dedicated to Isis Lochia. This inscription, ${ }^{33}$ offering the exact date of 22/21 BCE, is one of the earliest inscriptions in Macedonia that commemorates Isis as Lochia (image 2). ${ }^{34}$

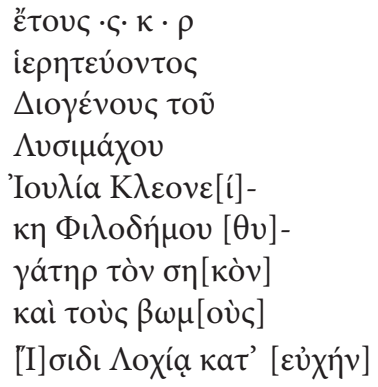

Translation: "In the year 126, (when) Diogenes, son of Lysimachos, was priest, Iulia Cleoneike daughter of Philodemos (dedicated) the cella and the altars to Isis Lochia [ex-voto]".

The information retrieved from this inscription is that a woman, named Iulia Cleoneike ordered the construction of a cella and altars in the sanctuary, honouring the goddess as Lochia. She does not, however, explain the reason for this donation, nor does other information on Isis Lochia exists in the same complex. Furthermore, there is no additional information about this woman.

However, she is not the only woman dedicating in the sanctuary of Thessalonica. Out of the sixteen inscriptions dedicated to the sanctuary by women ${ }^{35}$ eight of them refer to Isis ${ }^{36}$ while this is the only one referring to the goddess as Lochia. At the same time, the archaeological research has identified just one inscription of a woman commemorating an act of donation to the deities Serapis and Anubis ${ }^{37}$ and one more dedication towards Osiris, ${ }^{38}$ deities that were all worshipped in the same sanctuary.

32. On the inscription from the sanctuary see Bricault, 2005, pp. 136-166, $\mathrm{nn}^{\circ} 113 / 0501-113 / 0578$.

33. Now situated in the Archaeological Museum of Thessaloniki, $M \Theta 966$.

34. See IG X 2 1, 97; Pingiatoglou, 1981, p. 163, E62; Bricault, 2005, p. 145, nº 113/0523.

35. Inscriptions 113/0508, 113/0523, 113/0532, 113/0539, 113/0541, 113/0543, 113/0548, 113/0549, 113/0550, 113/0551, 113/0553, 113/0555, 113/0556, 113/0566, 113/0567, 113/0573 in Bricault, 2005.

36. Inscriptions 113/0508, 113/0523, 113/0532, 113/0549, 113/0550, 113/0551, 113/0555, 113/0566 in Bricault, 2005.

37. Inscription 113/0508 in Bricault, 2005.

38. Inscription 113/0553 in Bricault, 2005. 


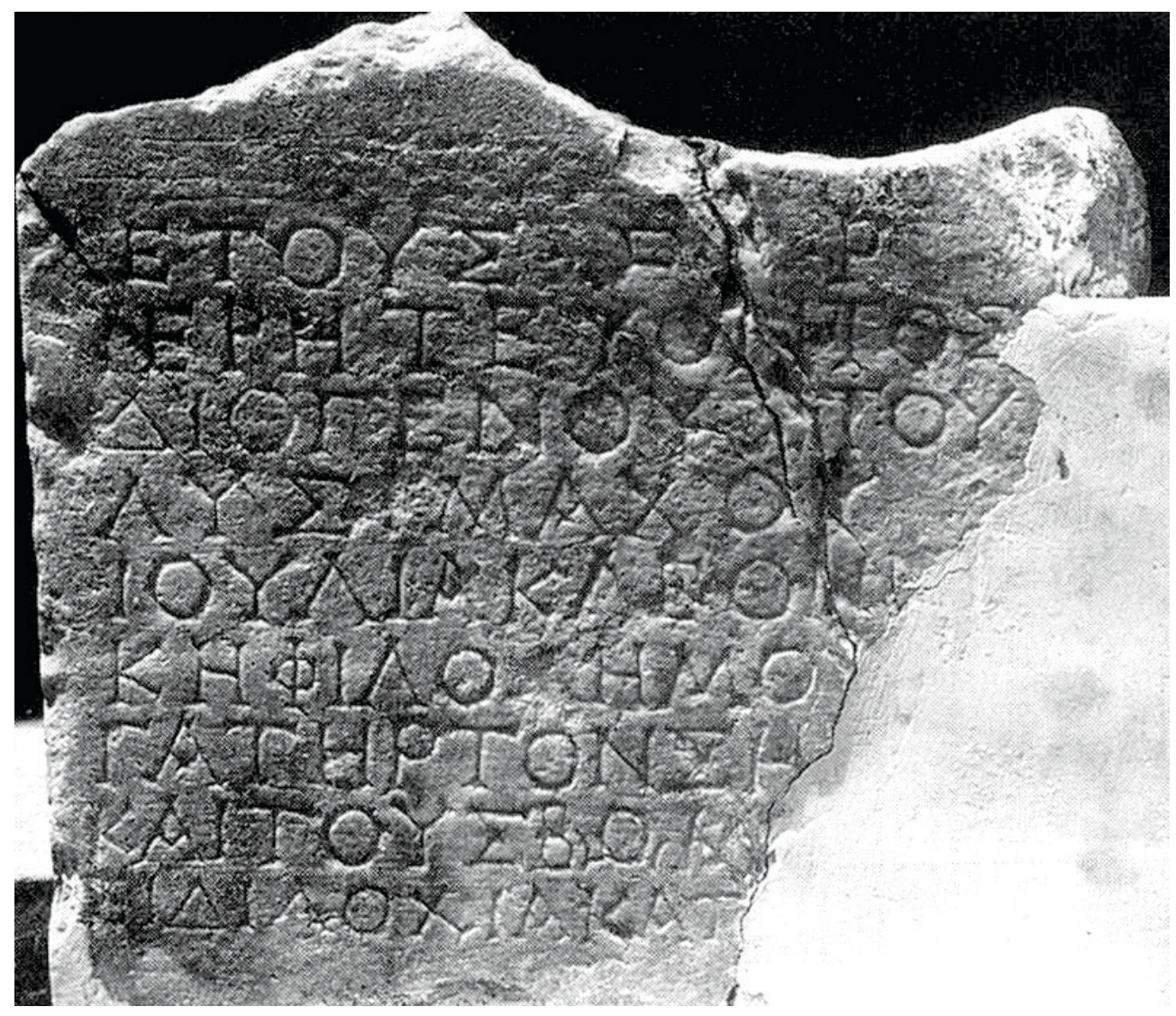

Image 2. Inscription to Isis Lochia from Thessalonica (Bricault, 2005, pl. XXIII).

Women are also connected to the reliefs representing vestigia and ears. In Thessalonica, a total number of six reliefs with footprints have been unearthed. ${ }^{39}$ Three of them preserve the names of three different women ${ }^{40}$ as the dedicators of these reliefs. The goddess appeared and helped them in a time of difficulty and for that reason, they commemorated this epiphany with the imprints that were left from her appearance.

39. These are the reliefs with inscriptions $113 / 0547,113 / 0555,113 / 0565,113 / 0566,113 / 0567$, 113/0568 in Bricault, 2005. On these reliefs see also Despinis et al., 1997, p. 65, $\mathrm{n}^{\circ} 48$ and Despinis et al., 2003, pp. 253-254, $\mathrm{n}^{\circ} 332-336$.

40. These are the reliefs with inscriptions 113/0555, 113/0566, 113/0567 in Bricault, 2005. 
Even though the name of Isis Lochia is not mentioned in any of these reliefs, a connection between safe childbirth and an epiphany of the goddess may be considered.

An analogous case is that of the reliefs representing ears. Of a total number of six reliefs found in the sanctuary and its surroundings, ${ }^{41}$ four of them are dedicated to Isis and three of them are dedicated by women. ${ }^{42}$ The goddess, as $\theta \varepsilon \dot{\varsigma} \varepsilon \dot{\varepsilon} \pi \dot{n} \kappa o o \varsigma$, heard their prayer and fulfilled their wish. The inscriptions do not provide enough information in order to ascertain the reasons behind these dedications. Nevertheless, it cannot be excluded that they may be connected to the dangerous period of pregnancy and healthy passage to motherhood. Besides, a woman offering such a gift to the goddess that protected her during childbirth is already known in Roman Macedonia. A votive relief decorated with a pair of ears dedicated by a woman to Artemis Lochia was found in a small village in Eordaia. ${ }^{43}$

Unfortunately, the excavations that revealed the sanctuary of Thessalonica, held in the first half of the $20^{\text {th }}$ century, were poorly documented and the unearthed buildings have been completely overbuilt by the modern city. The few existing reports ${ }^{44}$ focus only on two small temples and the sculptures coming from the surroundings of the sanctuary. The additional excavated buildings have been left completely undiscussed and the only plan of the sanctuary ${ }^{45}$ is not sufficient to identify the constructions offered by this woman, if they still existed at the time of the excavation. The sanctuary was in use for almost five centuries and, as a result, many changes in its layout occurred.

In addition, it is impossible to gain insights into the existence of a place used for the rites of passage happening after childbirth or for the use of water, a rather important element in the rituals of purification. The presence of water in the sanctuary has already been confirmed due to an inscription mentioning the presence of an hydreion ${ }^{46}$ and it is something that would be expected in a place honouring the Isiac deities. ${ }^{47}$ Nonetheless, it is difficult to understand its use in relation to the activities of purification. The sanctuary, although situated in the margins of the city and close

41. One of these reliefs is not accompanied by an inscription. This the relief M $\Theta 828$ in the Archaeological Museum of Thessaloniki. The other reliefs with inscriptions are the 113/0529, 113/0543, 113/0550, 113/0551, 113/0558 in Bricault, 2005. On these reliefs see also Despinis et al., 1997, pp. 66-68, $\mathrm{n}^{\circ} 49$ and $\mathrm{n}^{\circ} 51$ and Despinis et al., 2010, p. 206, n 529 .

42. These are the reliefs with inscriptions 113/0543, 113/0550, 113/0551 in Bricault, 2005.

43. On this relief see Chatzinikolaou, 2011, p. $277, \mathrm{n}^{\circ} 108$.

44. See BCH 1921, 540-541; BCH 1922, 527; BCH 1924, 497; and Makaronas, 1940, pp. 464-465.

45. See Steimle, 2008, 85, Abb 3.

46. See Bricault, 2005, nº 113/0521.

47. On water and the Isiac deities see Wild, 1981 and Kleibl, 2009, pp. 102-114. 
to the western city gate, was in a district known as the religious centre, close to other temples of the city. ${ }^{48}$

\title{
2. BEROEA
}

Isis Lochia is also present in the city of Beroea, a city situated approximately $75 \mathrm{~km}$ west of Thessalonica. The modern city of Verria is located where the ancient one used to be. Consequently, the majority of the excavations were rescue excavations which do not allow a deep understanding of the Roman city. ${ }^{49}$ The sanctuary of the Isiac deities is known only due to inscriptions found in second use, something that creates the serious problem of lack of context. The inscription ${ }^{50}$ that is dated to the first half of the $2^{\text {nd }}$ century $\mathrm{AD}$ and commemorates Isis Lochia was found in the Christian church of Hagios Georgios (image 3). ${ }^{51}$

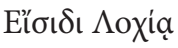

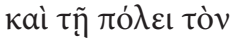 \\ $\beta \omega \mu$ òv àvé่ $\eta$ ка

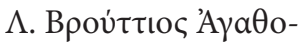

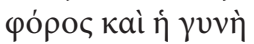 \\ aủToũ'E $\lambda \varepsilon v \theta \dot{\varepsilon} \rho เ o v$

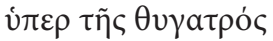

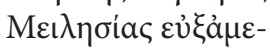

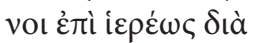

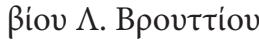

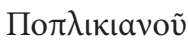

Translation: "To Isis Lochia and to the city, Lucius Bruttius Agathophorus and his wife Eleutherion consecrated this altar for their daughter Meilesia, after making the vow, during the priesthood for life of Lucius Bruttius Publicianus".

48. Vitti, 1996, pp. 88-92.

49. On the ancient city see Brocas-Deflassieux, 1999 and Tataki, 1988.

50. Now situated in the Archaeological Museum of Verria, $\mathrm{n}^{\circ} \Lambda$ 313. Dimensions: height $0,872 \mathrm{~m}$; width at the top $0,614 \mathrm{~m}$ and at bottom $0,642 \mathrm{~m}$; moulding from $0,074 \mathrm{~m}$ to $0,083 \mathrm{~m}$. Dimensions of the sistrum: height $0,165 \mathrm{~m}$. Dimensions of the letters: 1 st line $0,048 \mathrm{~m}$; 2nd line $0,041 \mathrm{~m}$; 3rd line $0,036 \mathrm{~m}$; 4 th to 9 th line (except of 7 th) $0,035 \mathrm{~m}$; 7th line $0,033 \mathrm{~m}$; 10 th line $0,03 \mathrm{~m}$; 11 th line $0,017 \mathrm{~m}$; interspace about $0,015 \mathrm{~m}$.

51. See Delacoulonche, 1858, p. 46; Demetsas, 1896, p. 71, nº 61; Cormack, 1945, pp. 105-106; SEG XII, n 316; Vidmann, 1969, p. 48; Tzanavari, 1993, pp. 1671-1672; Gounaropoulou and Chatzopoulos, 1998, p. 137, n 36; Bricault, 2005, p. 134, nº 113/0301. 


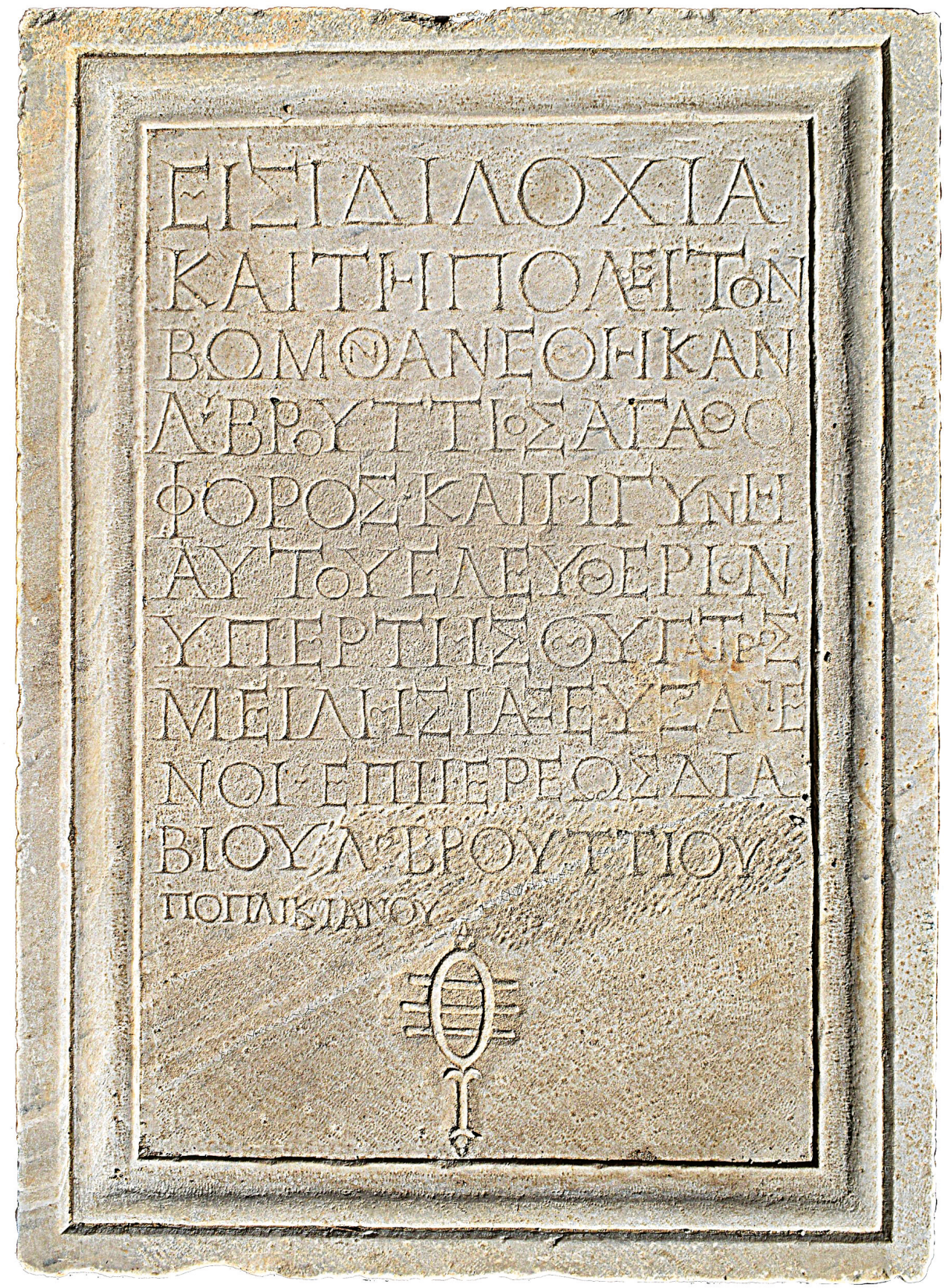

Image 3. Inscription to Isis Lochia from

Beroea (Ephorate of Antiquities of Imathia) 
This inscription declares that a couple, Lucius Bruttius Agathophorus and his wife Eleutherion, had made a vow to dedicate an altar to Isis and the city, if their daughter, Meilesia, was safely delivered. ${ }^{52}$ The parents addressed the goddess either to protect their daughter from the dangers of childbirth or because she was successfully delivered due to the assistance of Isis. ${ }^{53}$ The dedication of the newborn to the same deity that protected her birth shows that that the citizens of Beroea did not only recognize the goddess who protected childbirth in this divine figure, but also a goddess who took care of the nutrition of the newborn in order to provide both life and health. This theory is supported by the observation that Isis Lactans in the case of Macedonia, and especially in this case of Beroea, appears as Isis Lochia. ${ }^{54} \mathrm{It}$ is remarkable that in this case, the dedication to Isis Lochia comes not only from the woman who gave birth but from both parents.

It should be mentioned that the priest, who held this office for life, ${ }^{55}$ had also a lifelong office in the cult of Aphrodite Euschimon as another inscription of the $2^{\text {nd }}$ century AD from Beroea suggests. ${ }^{56}$ The connection of the cults of Aphrodite and Isis has been observed not only in the city of Beroea but also in two other cities of Macedonia. In Dion the same sanctuary that hosted the cult of Isis also hosted the cult of Aphrodite Hypolympidia ${ }^{57}$ while in Thessalonica two statues of Aphrodite were unearthed during the excavations of the sanctuary and it is believed that they belonged to the same sanctuary. ${ }^{58}$ As a result, it is possible that also in the case of Beroea Isis and Aphrodite were worshipped in the same complex..$^{59}$

A second inscription, that bears no mention of Isis Lochia but the circumstances of its dedication are analogous to the previous one was found in second use in

52. Cormack, 1945, 106.

53. Dunand, 1973b, 191

54. Tran tam Tinh, 1973, 22.

55. This is something not very common in Roman Macedonia as Tataki, 1993, 137 suggests. Analogous examples are known in other Isiac sanctuaries, as for example the one from Termessos in Pisidia (312/1501 in Bricault, 2005). Nevertheless, in Macedonia such lifelong offices were rare. The way for acquiring such a title varied, it could be either a hereditary position, it could be purchased or it could be an honorary attribution. On that see Christodoulou, 2009, pp. 346-347.

56. Tataki, 1993, p. 137; Gounaropoulou and Chatzopoulos, 1998, p. 125, nº 20.

57. See Pandermalis, 1982, p. 735; Pandermalis, 1989, p. 19; Pandermalis, 1997, p. 26.

58. See BCH 1921, 540; Makaronas, 1940, p. 465.

59. Gounaropoulou and Chatzopoulos, 1998, p. 126; Christodoulou, 2009, p. 347. 
another Christian church of the city, the church of Hagios Prokopios. This inscription has been dated between the $1^{\text {st }}$ and the $2^{\text {nd }}$ century $\mathrm{AD}^{60}$

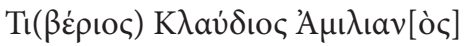

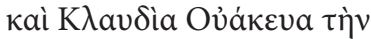

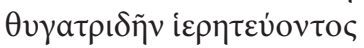

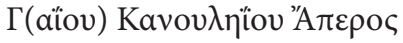

Translation: "Tiberius Claudius Amilianus and Claudia Vacua ${ }^{61}$ to their granddaughter, during the priesthood of Caius Canuleius Aper".

In this case, the grandparents of the newborn girl, Tiberius Claudius Amilianus and his wife commemorate the safe birth. The divine figure to whom they had prayed for this gracious intervention is not known, but it is possible that the responsible goddess would be Isis Lochia. It is interesting to note that in both cases from Beroea the newborn whose safe birth is celebrated is a girl.

Further evidence, that might verify the presence of Isis Lochia in the city is a marble piece found in second use as an architectural element in a Roman building. ${ }^{62}$ Its surface was inscribed with two footprints, each of a right foot of different dimensions while there is also an inscription under the footprints commemorating the same priest, Caius Canuleius Aper. ${ }^{63}$

Finally, in the same city another inscription, ${ }^{64}$ of the $3^{\text {rd }}$ century $\mathrm{AD}$, shows the coexistence of more than one deity protecting childbirth. ${ }^{65}$ The exact location of the place where the inscription dedicated to Artemis Eileithyia was found is not known, but it is important that the already existing deity, Eileithyia, did not disappear when Isis Lochia was introduced.

60. See Woodward, 1912, p. 150, $\mathrm{n}^{\circ}$ 8; Gounaropoulou and Chatzopoulos, 1998, p. 209, $\mathrm{n}^{\circ} 128$; Christodoulou, 2009, p. 345.

61. Transliteration proposed by Woodward, 1912, p. 150.

62. Now situated in the Archaeological Museum of Verria, $\Lambda 695$.

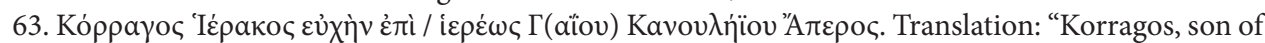
Hierax, as a vow, during the priesthood of Caius Canuleius Aper". See Allamani, 1988, p. 406; Tzanavari, 1993, p. 1673; Gounaropoulou and Chatzopoulos, 1998, p. 136, n 35; Bricault, 2005, p. 135, n 113/0302.

64. Now situated in the Archaeological Museum of Verria, $\Lambda 150$.

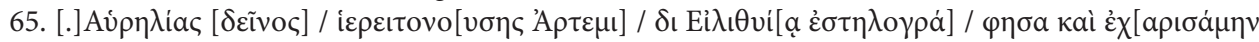

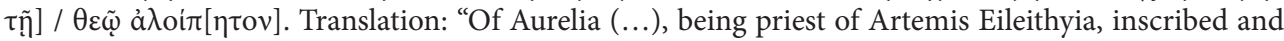
dedicated to the goddess without pain". See Gounaropoulou and Chatzopoulos, 1998, p. 153, n 50. 


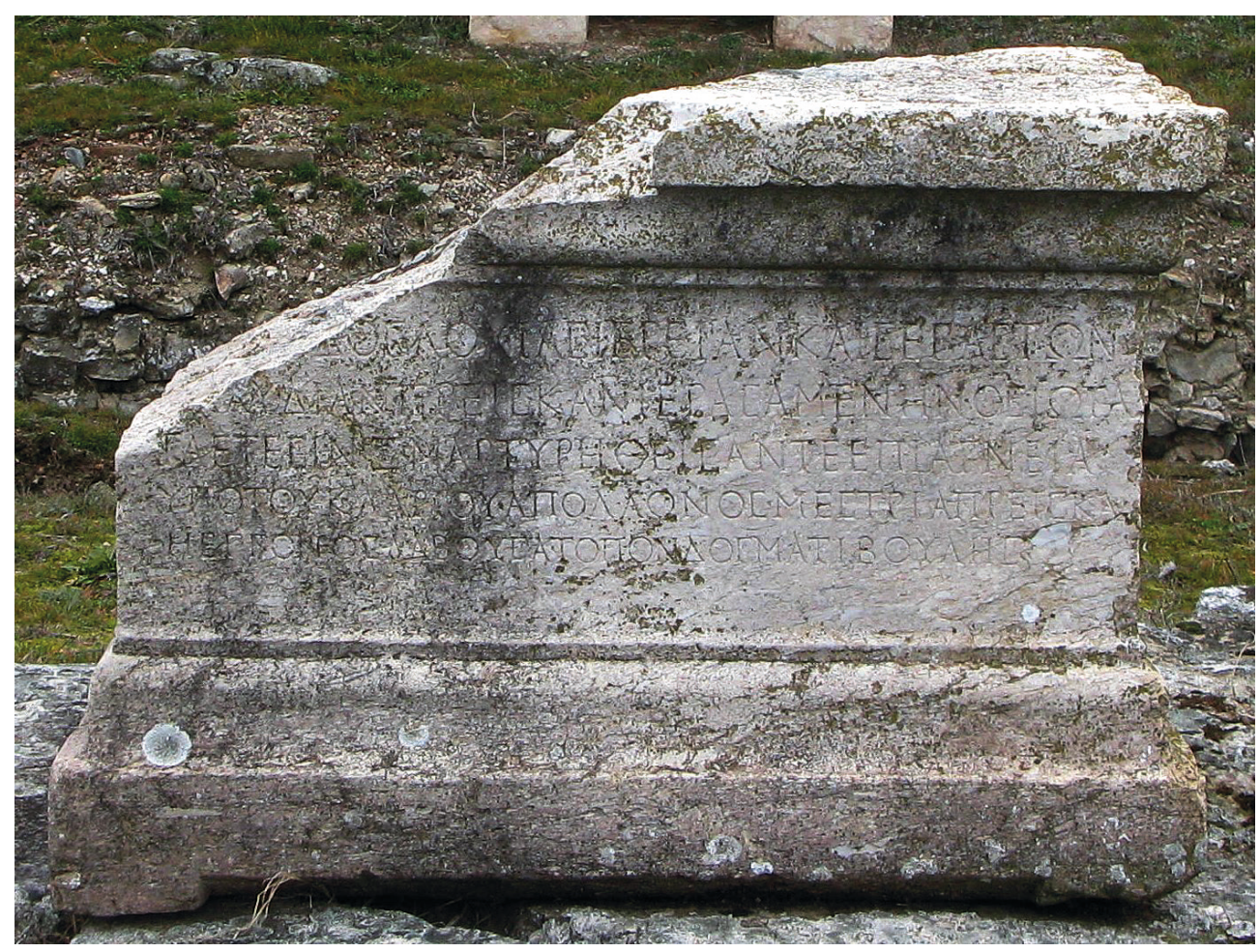

Image 4. Inscription of Isis Lochia from Stobi (photo by the author).

Despite the fact that the sanctuary has not yet come to light nor do the existing inscriptions provide enough information in order to reconstruct the identity of Isis in the city, the evidence suggests that Isis Lochia had a strong presence in Beroea. People of different ages and both genders would appeal to her and she would coexist with other deities protecting childbirth.

\section{Sтові}

The third city where Isis Lochia is present is Stobi, the ancient Paeonian settlement which lies at the confluence of the modern rivers Crna, the antique Erigon, and Vardar, the antique Axios. That the Isiac deities were venerated in the city was known 
long before the sanctuary was brought to light. ${ }^{66}$ The temple of Isis was identified in 2008. It is situated in the southeast part of the city, near the fortification wall and close to the river Erigon.$^{67}$ Nonetheless, the inscription ${ }^{68}$ dating to the $2^{\text {nd }}$ century $\mathrm{AD}$, that commemorates the presence of Isis Lochia in the city, was found many years before the excavation of the sanctuary, in 1931 (image 4). ${ }^{69}$

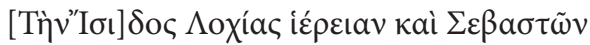

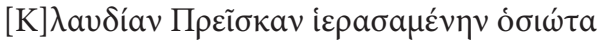

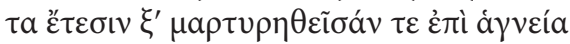

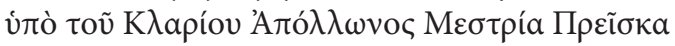

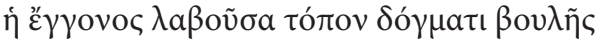

Translation: " (Statue of) the priestess of Isis Lochia and of Augusti, Claudia Prisca, who was very devoted priestess for sixty years, and was witnessed for her purity by Apollo Clarios. Mestria Prisca, her granddaughter on the place given by the decree of the Council’.

The first letters of the inscription are missing; it was hence initially thought that Claudia Prisca was a priestess of Artemis Lochia. ${ }^{70}$ The base was found during the excavation of 1931, built into a late Roman wall between the Episcopal Residence and the House of Parthenius. Additional misleading evidence was that close to the wall where the inscription was found, a small statuette of Artemis was also brought to light.

Christodoulou, however, made a new proposal..$^{71}$ According to him, it is a dedication towards a priestess that served a goddess who protected childbirth and, thus, Isis Lochia should also be considered. A closer study to the layout of the letters leads to the conclusion that the already proposed name would be too long for the available space. Subsequently, the only alternative would be the one of Isis as she is the only other goddess, known so far, who shares the same epithet of Lochia.

This inscribed base of the statue of Claudia Prisca is an honorary monument to a priestess who served Isis for more than sixty years. This woman was a member of the distinguished family of Prisci in Stobi. This is not the only public monument

66. See Blaževska and Radnjanski, 2015, p. 230.

67. On the sanctuary see Blaževska and Radnjanski, 2015.

68. Now in the archaeological site of Stobi. Dimensions: height $0,57 \mathrm{~m}$; length $0,83 \mathrm{~m}$; thickness 0,628 $\mathrm{m}$. Dimensions of the letters: height 0,025 m (lines 1-3) and 0,02 $\mathrm{m}$ (lines 4-5).

69. See Picard, 1957, pp. 113-114; SEG XVII, n 319; Wiseman, 1973b, pp. 152-164; Christodoulou, 2009, pp. 349-351; Babamova, 2012, p. 43, n 37; Christodoulou, 2015, p. 178.

70. See Picard, 1957, pp. 113-114; Wiseman, 1973, pp. 152-164; Pingiatoglou, 1981, pp. 163-164.

71. Christodoulou, 2009, pp. 349-351. 
commemorating members of this family. The inscription of a monument base mentions again Mestria Prisca who dedicated a monument to her mothers, Claudia Prisca and Aelia Priscila. ${ }^{72}$ It is important to note that, at that time, children regularly took at least one of their names from the nomen of the father. In this case, though, and probably due to the importance of the maternal line ${ }^{73}$ these women acquired their name from both their parents.

Claudia Prisca, who was a priestess of Isis Lochia and of the Augusti, was honoured by her granddaughter for performing the sacred rites for such a long time by erecting the statue with the inscribed base. No other information about the cult of Isis Lochia in Stobi can be obtained except for this dualism that connects one priest to more than one divine figures. ${ }^{74}$ The priestess remained pure during all these years as the oracle from Apollo at Clarus testifies, even though the reason Clarian Apollo would be invoked in this case remains unclear. ${ }^{75}$

What is sure is that the statue was not erected in the temple, but in a public place appointed by the Council. Today, the original place where the statue was located is not known; it would be a public place where someone would see other honorary monuments as well. Therefore, the importance of the social status of Claudia Prisca derives from the fact that she was at the same time priestess of the Augusti, that she held this office for a long period of time ${ }^{76}$ and that the place which would honour her memory was suggested by the Council.

The excavations in the sanctuary are still ongoing and so far the hypostasis of Isis Lochia has not been related to other artefacts coming from the sanctuary. The only evidence of the presence of the deity as a protector of women in childbirth remains this inscription.

\section{Dion}

The fourth city that is part of this endeavour is Dion. The sanctuary dedicated to the Isiac deities ${ }^{77}$ was located outside the south walls of the ancient sacred city of the

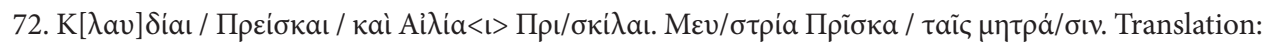
"Maestria Prisca for her mothers, Claudia Prisca and Aelia Priscila". On the inscription see Wiseman, 1973, pp. 151-152.

73. Wiseman, 1973, p. 157.

74. Christodoulou, 2009, p. 349.

75. On the relation of the city of Stobi and of the inscription to the sanctuary of Apollo at Clarus see the suggestion of Wiseman, 1973, pp. 174-181.

76. On the lifelong office of the priestess see again Christodoulou, 2009, pp. 346-347.

77. On the sanctuary see Pandermalis, 1982; Pandermalis, 1989; Pandermalis, 1997; Giuman, 1999. 
Roman Colonia Julia Augusta Diensis and not far from the river Vaphyras. ${ }^{78}$ Within this sanctuary three inscriptions dedicated to Isis Lochia have been brought to light, which has led some researchers ${ }^{79}$ to the conclusion that Isis Lochia was the principal divinity honoured during Roman times in this complex.

The first of the three inscriptions was found on the stairs that led to the main temple just after entering the tetrastyle ionic prostasis. A small pedestal held a small rectangular slab with footprints representing a larger and a smaller right foot. On the pedestal the inscription ${ }^{80}$ of the $2^{\text {nd }}$ century $\mathrm{AD}$ revealed the information about the dedicator and the deity being honoured (image 5). ${ }^{81}$

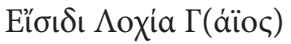

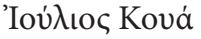 \\ $\rho \tau o \varsigma \delta \tilde{\omega} \rho \circ$
}

Translation: “To Isis Lochia, Caius Iulius Quartus, (offers this) gift”.

It is the first case where a man alone is commemorated as the person who dedicates to Isis Lochia. The reason which led him to such a gesture is unknown. He may be the husband or the father who asked the goddess for her divine intervention. The representation of two different feet, one larger and one smaller, can be understood as the foot of the human and the foot of the divine figure. ${ }^{82}$ However, more theories have been proposed regarding the interpretation of the different size of feet. Pandermalis ${ }^{83}$ has suggested that the different feet correspond to the couple, both the man and the

78. The river nowadays flows on the west side of the sanctuary, between the sanctuaries of Isis and Zeus Hypsistos. Nonetheless, this riverbed was only created in 1951. The river has changed its flow several times since the construction of the Hellenistic city of Dion. The previous riverbeds were definitely on the east of the sanctuary of Isis but it is still not known exactly at what distance. It is important to keep in mind, however, that even though the path of the ancient river cannot be followed in this area, water was present in both the above-mentioned sanctuaries due to the existence of natural springs.

79. See Wild, 1984, 1841.

80. Now situated in the Archaeological Museum of Dion, $n^{\circ} 424$. Dimensions: height 0,49 m; length $0,39 \mathrm{~m}$; thickness $0,35 \mathrm{~m}$. Dimensions of the letters: height from $0,032 \mathrm{~m}$ to $0,044 \mathrm{~m}$; interspace $0,015 \mathrm{~m}$.

81. See Pandermalis, 1984, p. 273; SEG XXXIV, n 622; Bricault, 2005, n 113/0201; Christodoulou, 2011, p. 18.

82. This proposition is sustained by Bricault, 2005, p. 162, on his comments on 1113/0566 and Christodoulou, 2011, p. 22. In general, for different interpretations of the footprints see for example Castiglione, 1968; Dunbabin, 1990; Gasparini, forthcoming, with all previous bibliography.

83. Pandermalis, 1984, p. 274. 


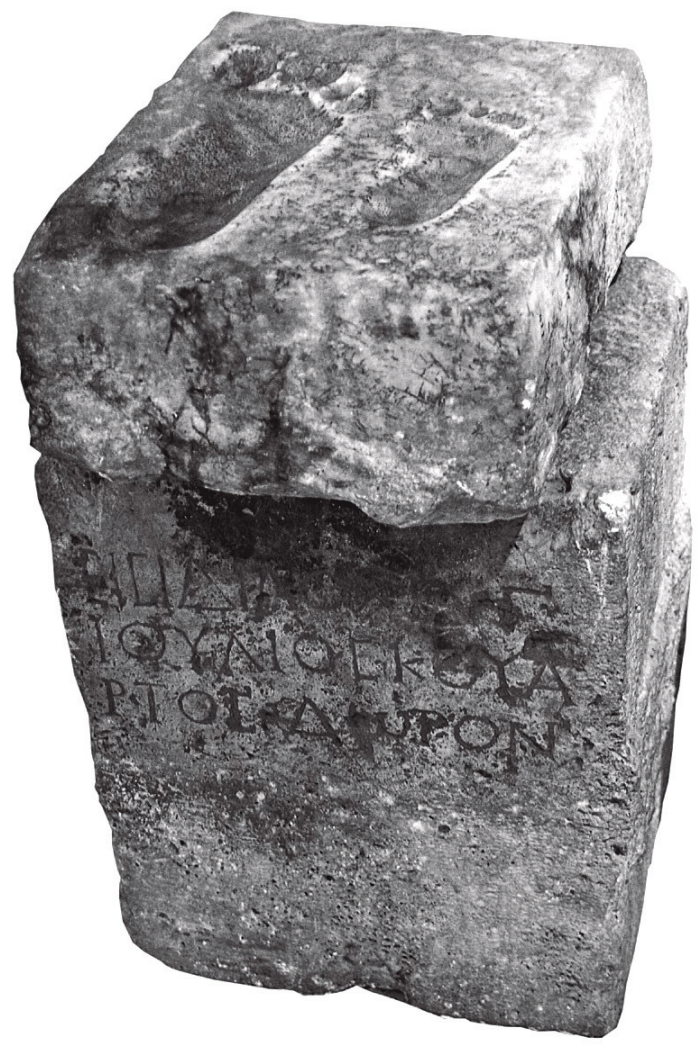

Image 5. Inscription to Isis Lochia from Dion (Christodoulou, 2011, p. 19, fig. 10).

woman, that arrived at the temple in order to thank the goddess while Voutiras ${ }^{84}$ has proposed that the small one belongs to a child, probably Harpocrates.

The exact same inscription was found in the temple of Isis Tyche, in front of her statue. It is a support for an ex-voto which bears the same dedication from the same man to the same deity. ${ }^{85}$

The last inscription was found on the steps of the main temple, situated on the fifth and last step before the entrance to the pronaos. The slab ${ }^{86}$ has a representation

84. Despinis et al., 2003, p. 254.

85. See Pandermalis, 1984, pp. 274-275; SEG XXXIV, $\mathrm{n}^{\circ}$ 627; Bricault, 2005, $\mathrm{n}^{\circ}$ 113/0218.

86. Now situated in the Archaeological Museum of Dion, $\mathrm{n}^{\circ} 421$. Dimensions: height $0,335 \mathrm{~m}$; length $0,15 \mathrm{~m}$; thickness 0,06 m. Dimensions of the ear: height 0,10 m.; length 0,065 m. Dimensions of the 
of an ear accompanied by the inscription that Christodoulou dates to the $2^{\text {nd }}$ or the $1^{\text {st }}$ century $\mathrm{BC}$ due to the shape of the letters ${ }^{87}$ something that would make it the oldest found in Macedonia (image 6). ${ }^{88}$

'Ió $\sigma \omega v$

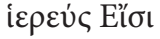

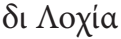

Translation: "Iason, priest, to Isis Lochia”.

This is the second case where a man alone dedicated to Isis Lochia. He was a priest and he dedicated a votive relief which represented an ear showing that Isis has heard his prayers.

The sanctuary of Dion is a site which provided researchers with an important number of inscriptions. A total number of nineteen inscriptions was unearthed, although not all were in their primary context. ${ }^{89}$ These inscriptions make evident that the presence of women in the sanctuary was noteworthy, albeit they were not all connected to Isis Lochia. Nine inscriptions dedicated by women ${ }^{90}$ have been brought to light inside the sanctuary while four of them were dedicated to Isis. ${ }^{91}$ There are also three inscriptions dedicated to other women of the city. ${ }^{92}$ Furthermore, it is important that from the total of nineteen inscriptions, five represent footprints ${ }^{93}$ and two represent ears. ${ }^{94}$ The presence of women is, therefore, highlighted as they dedicated

letters: from $0,14 \mathrm{~m}$ to $0,16 \mathrm{~m}$; interspace from 0,005 to $0,006 \mathrm{~m}$.

87. Christodoulou, 2011, p. 18. It is important to take into account that Bricault and Dionysopoulou, 2016, p. 41 propose a date to the imperial period. The excavator (Pandermalis, 1989, p. 16) suggests a date for the architectural remains of the sanctuary to the $2^{\text {nd }}$ century AD. Nonetheless, there is at least one more votive relief and a statue that come from the Hellenistic period and were reused in Roman times. The sequence of phases and the reuse of material has caused a discordance among the scholars who have proposed different dates for different artefacts found in the sanctuary. Since the excavation data has not yet been thoroughly published the matter remains unclear.

88. See Pandermalis, 1984, p. 274; SEG XXXIV, n 626; Bricault, 2005, $n^{\circ}$ 113/0202; Christodoulou, 2009, p. 344; Christodoulou, 2011, p. 16.

89. On the inscriptions see Pandermalis, 1984 and Bricault, 2005, pp. 130-134.

90. Inscriptions 113/0206, 113/0207, 113/0208, 113/0209, 113/2010, 113/0211, 113/0212, 113/0215, 113/0219 in Bricault, 2005.

91. Inscriptions 113/0207, 113/0211, 113/0212, 113/0219 in Bricault, 2005.

92. Inscriptions 113/0204, 113/2010, 113/0213 in Bricault, 2005.

93. Inscriptions 113/0201, 113/0203, 113/0205, 113/0206, 113/0218 in Bricault ,2005.

94. Inscriptions 113/0202, 113/0217 in Bricault, 2005. 


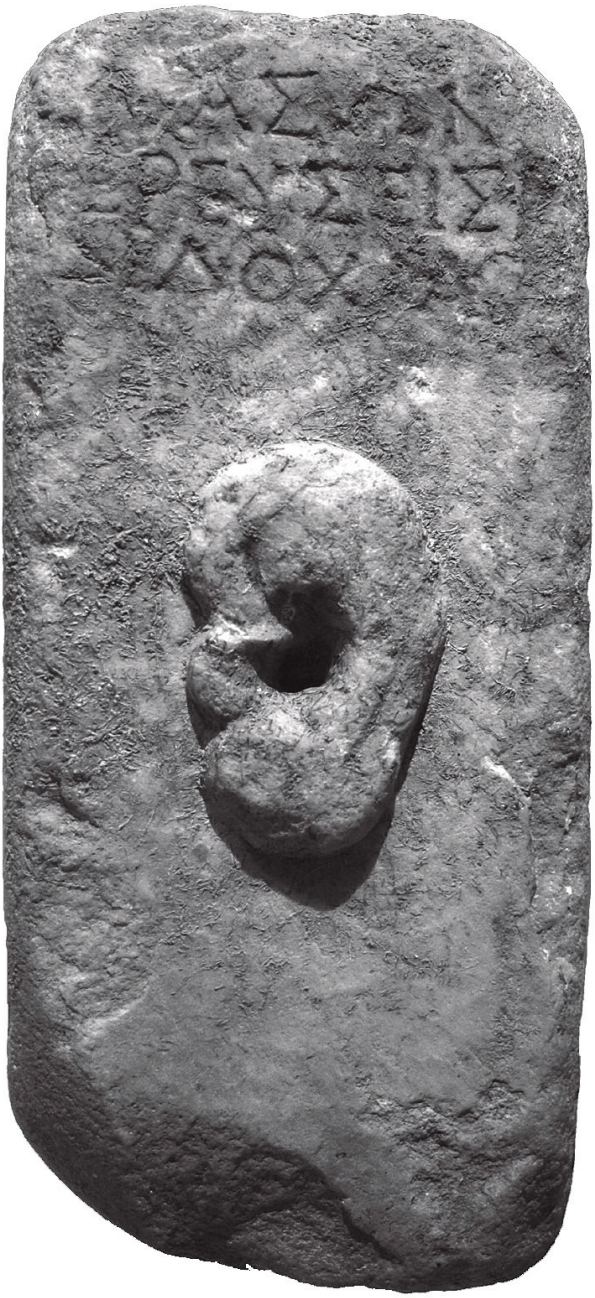

Image 6. Inscription to Isis Lochia from Dion (Christodoulou, 2011, p. 17, fig. 8).

also to different gods, like Hermanubis or even offered money for the construction of parts of the sanctuary.

Another inscription brought to light at the same site should be taken into account critically. It is a Hellenistic inscription dedicated to Artemis Eileithyia. ${ }^{95}$ The fact that it was found in the same sanctuary led to the conclusion that the cult of

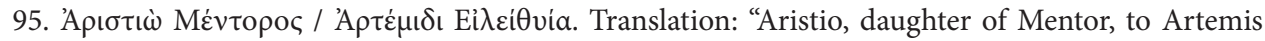
Eileithyia”. See Pandermalis, 1984, p. 275; SEG XXXIV, nº 629; Bricault, 2005, p. 133, n 113/0215. 
Artemis Eileithyia pre-existed at the same site and was replaced by Isis Lochia during the Roman period. ${ }^{96}$ Even though the evidence for supporting such a theory is not sufficient as there is no clear stratigraphy of the sanctuary due to the difficulties of the excavation, the inscription makes clear that Isis Lochia was not the first deity who assisted childbirth at Dion. ${ }^{97}$ Whether the cult of Artemis Eileithyia was replaced by Isis Lochia or the two cults coexisted, as in the case of Beroea, is something that the archaeological data have not sufficiently answered yet.

The significance of water in various manifestations of the Isiac cult is well accepted..$^{98}$ Could water also be related to fertility, reproduction, childbirth, and maternity in the case of Dion? In antiquity, water surging up from the earth in the sacred enclosures was identified to gifts of both physical and mental health. ${ }^{99}$ Rivers and streams were believed to cure infertility and to accelerate or ease delivery. Such are the examples from Athens, where the river Kephisos is described as birth-hastening and the stream Kyllypera, in the foothills of mount Hymettos, was credited with the power to promote an easy delivery and to cure sterile women. ${ }^{100}$ In the Isis sanctuary of Dion, the temple of Isis Tyche, located south of the main temple, was constructed on a spring. Analogous is the case of the temple of Aphrodite Hypolympidia, located north of the main temple, which, in addition, had an underground system of pipes. ${ }^{101}$ Whether Vaphyras was used for such activities remains an open question as the riverbed has been relocated several times throughout the centuries and the topographic relation between the river and the sanctuary remains obscure. It cannot be excluded, though, that the construction of the two small temples in proximity to the streams and running water implies its multipurpose use.

A second question is whether the extra-urban location of the sanctuary can be related to the above-mentioned rituals. A birth was a transitional state, involving risk, the outcome of which was not easy to predict. For that reason, a transitional space was also required and the rites of purification would not take place inside the city but outside, in order to protect the social actors. Giuman ${ }^{102}$ argues that the location of the sanctuary of Isis was characterised by these specific ritual functions and compares the site to Artemision of Brauron and the sanctuary of Artemis Lochia in mount

\footnotetext{
96. Pandermalis, 1982, p. 732.

97. On the transition of the cult of Artemis Eileithyia to Isis Lochia in Dion see also Giuman, 1999.

98. On that see Wild, 1981 and Kleibl, 2009, pp. 102-114.

99. Cole, 2004, p. 193.

100. Garland, 1990, p. 68.

101. Pandermalis, 1989, p. 20.

102. Giuman, 1999, pp. 442-444.
} 
Cynthus on Delos. However, the case of Dion is quite particular. The sanctuary of Isis is not the only extra-urban sanctuary. On the contrary, all the sanctuaries of Hellenistic and Roman Dion where situated extra muros and close to each other. ${ }^{103}$ As a result, the location of the temple in relation to the urban grid might not be connected to the rituals taking place in that sanctuary, but to the old tradition deriving from the creation of the sanctuary of Zeus Olympios in that area.

\section{Birth Deities in Macedonia}

It has already been shown that Isis was not the only deity protecting childbirth nor did this divine role appear in the Roman period. Birth deities already existed in Macedonia. Both in the cases of Beroea and Dion, there are inscriptions that declare that more than one such deities coexisted in the same city or were replaced by others as the years passed. Especially in Dion, apart from the already mentioned Hellenistic inscription to Artemis Eileithyia in the sanctuary of Isis, a second inscription reveals the presence of Eileithyia in the sacred area. It was found in the nearby sanctuary of Demeter ${ }^{104}$ and it is a fragmented base of a statue also dated to the Hellenistic period. ${ }^{105}$ Whether the inscription suggests a veneration of the deity protecting childbirth in the same sanctuary where Demeter, protector of the rebirth of land, was worshipped or whether it was transported there from the nearby sanctuary of Isis is an open question. ${ }^{106}$

There are a few other cases from Macedonia that testify to the presence of divine figures safeguarding childbirth through the centuries. In Pydna, Eileithyia is mentioned in one base ${ }^{107}$ found in the necropolis of the city. The veneration of Eileithyia in Pydna has caused a vivid discussion. The inscription has been related to a sanctuary of the Hellenistic period, identified by some scholars as a sanctuary dedicated to Eileithyia. ${ }^{108}$ However, another theory has been expressed, suggesting a veneration of Asclepios in the sanctuary and maybe his coexistence with other deities, such as Eileithyia. ${ }^{109}$

103. Christodoulou, 2011, p. 22.

104. The two sanctuaries have a distance between them of no more than $150 \mathrm{~m}$.

105. Now situated in the Archaeological Museum of Dion, $M \Delta 3099$. The front of the base bears the

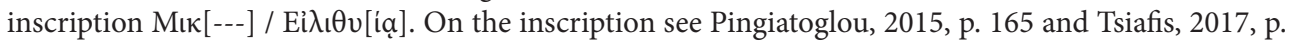
438.

106. Pingiatoglou, 2015, p. 165.

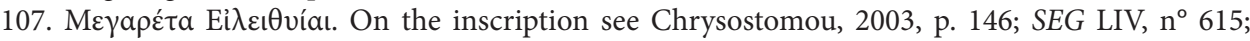
Tsiafis, 2017, p. 438.

108. Chrysostomou, 2003, pp. 146-148.

109. Tsiafis, 2017, p. 175. 
In Amphipolis, in 1983, the excavation of the western Roman city wall brought to light different marble artefacts and fragmented inscriptions among which a dedication to Artemis Eileithyia. ${ }^{110}$ In Karyochori, in Eordaia, a Roman marble votive relief representing a pair of ears was dedicated to Artemis Lochia. ${ }^{111}$ Finally, on the island of Thasos, a stela found in 1958, which is dated between the end of the $2^{\text {nd }}$ century $\mathrm{BC}$ and the $1^{\text {st }}$ century $\mathrm{AD}$, commemorates Artemis Eileithyia. ${ }^{112}$

\section{Conclusions}

The cases from Macedonia prove that Isis Lochia was not alone in these sanctuaries. A birth deity was a deity that could coexist with other gods, either healing gods ${ }^{113}$ or deities protecting the rebirth of the land. ${ }^{114}$ Simultaneously, Isis not only coexisted with the other deities of the gens Isiaca but also with other divine figures of the Greek pantheon. In the case of Dion, Artemis and Isis were closely connected. Aphrodite was another divine figure related to Isis in Dion, Beroea and probably Thessalonica. Subsequently, each activity of human life was protected by more than one gods and Isis protected multiple activities at the same time, being related to numerous deities and their rituals.

Water was central to the rituals associated with women and the activities of raising children. In addition, water facilities washed away the dangers and provided a means of purification upon entering a sanctuary. In the Isiac sanctuaries the presence of water is expected. Therefore, in the case of Thessalonica the hydreion ${ }^{115}$ should not be related to Isis Lochia. In Stobi, although the sanctuary was close to the river no relation has so far been testified. Only in the case of Dion, the streams existing inside the sanctuary might have such a significance. It should not be forgotten, though, that, purification after childbirth was obtained through numerous rites. ${ }^{116}$

110. Lazaridis, 1983, p. 38.

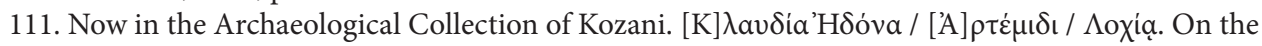
inscription see Chatzinikolaou, 2011, p. 277.

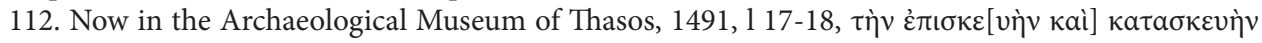

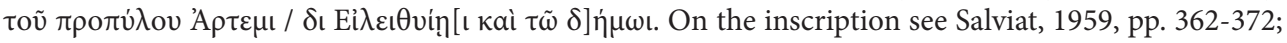
Pingiatogolou, 1981, p. 164.

113. On the coexistence of Eileithyia with Asclepios see Pingiatoglou, 1981, p. 92 and Tsiafis, 2017, p. 175.

114. Pingiatoglou, 2015, p. 165.

115. Bricault, 2005, p. 144, $\mathrm{n}^{\circ} 113 / 0521$.

116. On the purification rites after birth see Parker, 1983, pp. 32-73. See also Mehl, 2009, pp. 201-203. 
Rituals are emotionally loaded occasions. They can be defined as attempts by humans to communicate with the gods although their positive outcome is not guaranteed. ${ }^{117}$ Every different deity would decide for every different case whether they would listen to someone praying or whether they would ignore them. When a prayer was fulfilled a sequence of acts of reciprocity occurred. In the case of Isis Lochia, firstly, help was requested by the woman in labour or her relatives; secondly, that help was offered by the divine figure; then the human, mother or family, should honour the goddess and commemorate this event in order to ask for the same help again in the future.

It is notable that linguistically the notion of thanking and commemorating are still related in modern languages. The term "thanks" in the Germanic languages has developed from a concept that means "to think" or "to commemorate" (denken means to think while gedenken means to commemorate). In addition, the concept of gratitude, of thanking, is expressed by the commemoration of a favour, something for which the person needs to give thanks. ${ }^{118}$ The case studies that have been presented offer information which reconstructs the commemorating activities of gratitude from the social actors towards Isis Lochia. These inscriptions are the material evidence allowing an understanding of the creation of such a religious memory.

A female in childbirth, at the moment when she was ready to make the most important contribution to her family but also to the community where she belonged, was, in ritual terms, as farthest as possible from the divine. It was a dangerous and difficult moment, a moment of transition for both mother and newborn. Death during childbirth was common to women coming from all different social classes. ${ }^{119} \mathrm{~A}$ high level of anxiety is, hence, to be expected. This anxiety about the future of the parturient but also of her offspring reflects both the risk and the significance of the process of childbirth. ${ }^{120}$ Therefore, the family needed to thank the deity for the successful transition through this fragile state.

Even though reproduction and childbirth were handled almost exclusively by women, ${ }^{121}$ and the cult of the protecting deities was almost exclusively addressed to women, this is not the case with Isis Lochia. Women were not the only ones engaged in the rituals. Both parents prayed to the goddess and both men and women were involved in the cere-

117. Chaniotis, 2011b, p. 265.

118. Versnel, 1981, p. 46.

119. Hänninen, 2005, pp. 53-54. On the iconographic representations of such scenes see also Latini, 2011.

120. Cole, 2004, p. 113.

121. Latini, 2011, p. 69. 
monies. ${ }^{122}$ The cases from Macedonia show that both Roman and Greek men and women had an active role in the cult of Isis Lochia as priests but also as dedicators. It has also been shown that a large family circle was involved; not only the parents but the grandparents too would dedicate to the deity. They sought help and Isis Lochia, through her priests or through an epiphany, would answer their plea for help. They would go to the sanctuaries and make offerings in order to ask or to thank for the successful resolution of the life-changing event of their family. The divine will would be served through an epiphany but the communication of that person with someone serving the divine will inside the temple would happen through the priests and priestesses. Thus, their role would also have great significance. In both cases of Beroea and Stobi, it has been noticed that priesthood was a lifelong office, its importance is therefore highlighted.

The divine agency was commemorated in various ways. Marble slabs of footprints reveal the appearance of the goddess. In other cases, votive reliefs representing ears made evident that Isis Lochia had heard and had protected those women. In some cases, their gratitude was expressed with the donation of money for the repairing or creation of a temple, an altar or statues.

All this vivid activity should be understood within its context. Even though only the aforementioned inscriptions have survived, their context would include wooden or textile dedications, statues and statuettes of different materials, temples and altars. The sanctuaries were the house of the deity and the place where the devoted would offer their dedications. ${ }^{123}$ Public religious festivals were held in order to obtain purification and fertility but also for expressing their gratitude. ${ }^{124}$

In conclusion, the role of women as the ones who carried new life was of major importance as the birth of a child was the purpose of marriage. At the same time, it entailed risks. As a result, a deity who would assist at childbirth was necessary. The large number of deities protecting this transitional state, among whom was Isis Lochia, is a reflection of the dangers and the anxiety generated by childbirth. For that reason, no single deity ever succeeded in establishing outright control of this branch of human activity. ${ }^{125}$ In the case of Roman Macedonia, Isis Lochia had a prominent role in the Imperial period. Nonetheless, she was not the only one offering that kind of help as she coexisted with other divine figures which were present in the same religious landscape before and after her arrival.

122. Heyob, 1975, p. 81.

123. See for example Demand, 1994, p. 90; Cole, 2004, pp. 214-218; Kraemer, 1992, p. 23. Women would dedicate various different objects to the deity as textiles or tools used in spinning and weaving.

124. Hänninen, 2005, pp. 5-53.

125. Garland, 1990, p. 68. 


\section{BibLIOGRAPHY}

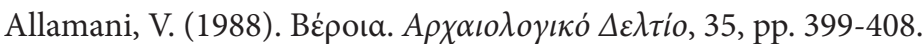

Babamova, S. (2012). Inscriptiones Stoborum. Stobi: National Institution for Management of the archaeological site of Stobi.

Blaževska, S. and Radnjanski, J. (2015). The Temple of Isis at Stobi. In Nikoloska and Müskens, 2015, pp. 215-256.

Bodiou, L. and Mehl, V. (2009). La religion des femmes en Grèce ancienne. Mythes, cultes et société. Rennes: Presses universitaires de Rennes.

Bricault, L. (2001). Atlas de la diffusion des cultes isiaques. Paris: Diffusion de Boccard.

Bricault, L. (2005). Recueil des inscriptions concernant les cultes Isiaques (RICIS), vol 1. Paris: Académie des inscriptions et belles-lettres.

Bricault, L. (2006). Isis, Dame des flots. Liege: Centre Informatique de Philosphie et Lettres.

Bricault, L. and Bonnet, C. (eds.) (2013). Panthée: Religious Transformations in the GraecoRoman Empire. Leiden and Boston: Brill.

Bricault, L. and Dionysopoulou, E. (2016). Myrionymi 2016. Épithètes et épiclèses grecques et latines de la tétrade isiaque. Toulouse: no publisher.

Bricault, L. and Versluys M.J. (eds.) (2010). Isis on the Nile, Egyptian Gods in Hellenistic and Roman Egypt. Leiden and Boston: Brill.

Bricault, L., Versluys, M.J. and Meybloom, P. (eds.) (2007). Nile into Tiber. Egypt in the Roman World. Leiden and Boston: Brill.

Bricault, L. and Veymiers, R. (eds.) (2011). Bibliotheca Isiaca II. Bordeaux: Ausonius.

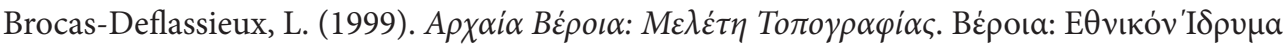

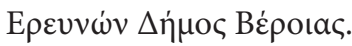

Bruit Zaidman, L. (1996). Le temps des jeunes filles dans la cite grecque: Nausicaa, Phrasikleia, Timareta et les autres. Clio. Femmes, Genre, Histoire, 4, pp. 33-50.

Brulé, P. (1996). Des osselets et des tambourins pour Artémis. Clio. Femmes, Genre, Histoire, 4, pp. 11-32.

Castiglione, L. (1968). Inverted footprints. A contribution to the ancient popular religion. Acta Etnographica Academiae Scientiarum Hungaricae, 17, pp. 121-137.

Chaniotis, A. (ed.) (2011a). Ritual Dynamics in the Ancient Mediterranean: Agency, Emotion, Gender, Representation. Stuttgart: F. Steiner

Chaniotis, A. (2011b). Emotional Community through Ritual: Initiates, Citizens, and Pilgrims as Emotional Communities in the Greek World. In Chaniotis, 2011a, pp. 264-290.

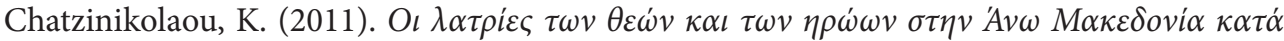

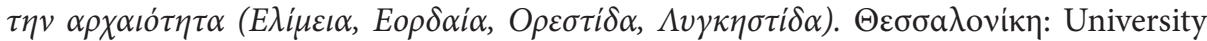
Studio Press.

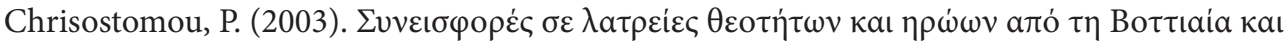

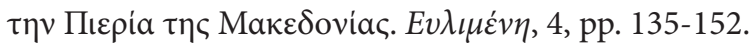

Christodoulou, P. (2009). Priester der ägyptischen Götter in Makedonien. Mitteilungen des Deutschen Archäologischen Instituts Athenische Abteilung, 124, pp. 325-356. 
Christodoulou, P. (2011). Les reliefs votifs du sanctuaire d' Isis à Dion. In Bricault and Veymiers, 2011, pp. 11-22.

Christodoulou, P. (2015). Sarapis, Isis and the Emperor. In Nikoloska and Müskens, 2015, pp. 167-214.

Coche de La Ferte, E. (1975). Un bracelet d'époque romaine à usage obstétrique. Syria, 51, pp. 265-289.

Cole, S.G. (2004). Landscapes, Gender and Ritual Space. Berkeley, Los Angeles and London: University of California Press.

Collart, P. (1929). Le Sanctuaire Des Dieux Egyptiens A Philippes. Bulletin de Correspondance hellénique, 53, pp. 70-101.

Cormack, J.M.R. (1945). Inscriptions from Beroea. The Annual of the British School at Athens, 41, pp. 105-114.

Delacoulonche, A. (1858). Mémoire sur le berceau de la puissance Macédonienne, des bords de l'Haliacmon à ceux de l'Axius. Paris: Nabu Press.

Demand, N. (1944). Birth, death and the motherhood in Classical Greece. Baltimore and London: Johns Hopkins University Press.

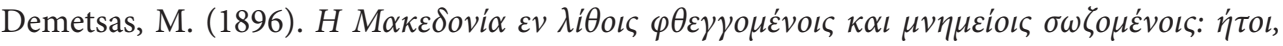

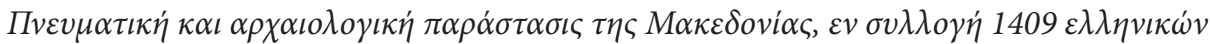

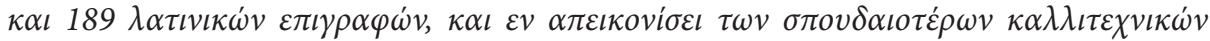

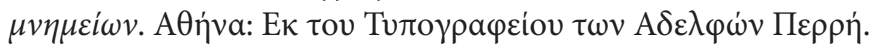

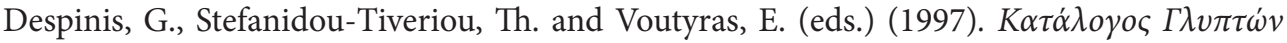

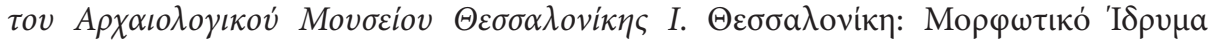

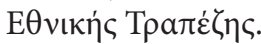

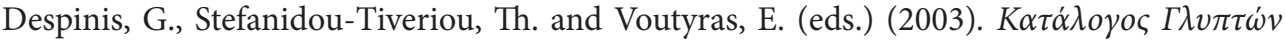

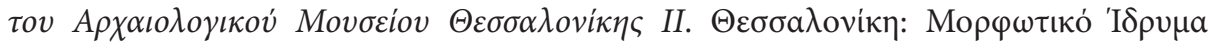

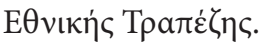

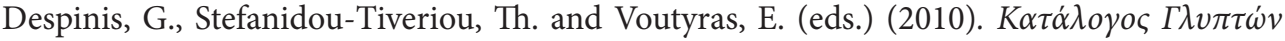

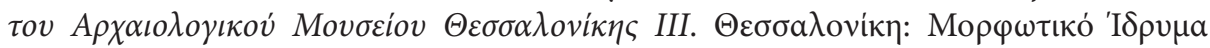

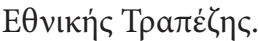

Dunand, Fr. (1962). Une 'interpretatio romana' d'Isis: Isis Déesse des naissances. Revue des Études Latines, 40, pp. 83-86.

Dunand, Fr. (1973a). Le culte d'Isis dans le bassin oriental de la Méditerranée: Le culte d'Isis et les Ptolémées. Leiden: Brill.

Dunand, Fr. (1973b). Le culte d'Isis dans le bassin oriental de la Méditerranée: Le culte d'Isis en Grèce. Leiden: Brill.

Dunand, Fr. (1979). Religion populaire en Egypte Romain. Leiden: Brill.

Dunand, Fr. (2013). Images de Dieux en Dialogue. In Bricault and Bonnet, 2013, pp. 191-232.

Dunbabin, K. (1990). Ipsa deae vestigia... Footprints divine and human on Graeco-Roman monuments. Journal of Roman Archaeology, 3, pp. 85-109.

Garland, R. (1990). The Greek way of life. New York: Duckworth. 
Gasparini, V. (forthcoming). Isis' Footprints. The Petrosomatoglyphs As Spacial Indicators Of Human-Divine Encounters.

Giuman, M. (1999). Metamorfosi di una dea: da Artemide ad Iside in un santuario di Dion. Ostraka, 8, pp. 427-446.

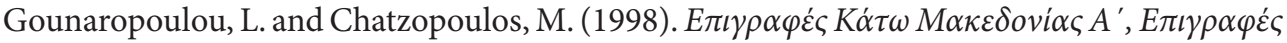

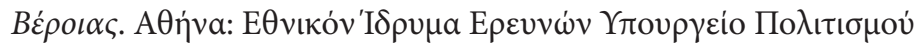

Grenfel, B. and Hunt, A. (1915). The Oxyrhynchus Papyri. Part XI. London: Egypt Exploration Fund.

Hänninen, M.-L. (2005). From womb to family. Rituals and social conventions connected to Roman birth. In Mustakallio, Hanska, Sainio and Vuolanto, 2005, pp. 45-59.

Hart, G. (2005). The Routledge dictionary of Egyptian Gods and Goddesses. New York and London: Routledge.

Heyob, S.K. (1975). The cult of Isis among women in the Graeco-Roman world. Leiden: Brill.

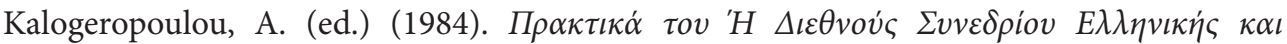

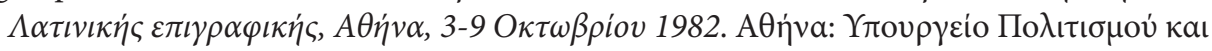
$\mathrm{E} \pi \mathrm{\tau} \tau \mu \omega \dot{\omega}$.

Kleibl, K. (2009). Iseion : Raumgestaltung und Kultpraxis in den Heiligtümern gräco-ägyptischer Götter im Mittelmeerraum. Worms.

Kraemer, R.S. (1992). Her Share of the Blessings. New York and Oxford: Oxford University Press.

La Torre, G.F. and Torelli, M. (eds.) (2011). Pittura Ellenistica in Italia e in Sicilia. Linguaggi e tradizione. Roma: $\mathrm{G}$, Bretschneider.

Latini, A. (2011). Riflessi della mortalità neonatale e materna nella pittura ellenistica. In La Torre and Torelli, 2011, pp. 63-77.

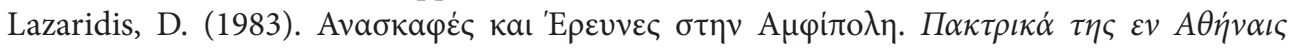

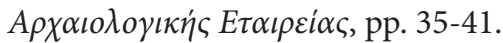

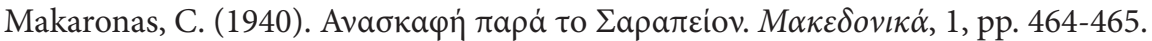

Malaise, M. (2005). Pour une terminologie et une analyse des cultes isiaques. Bruxelles: Académie Royale de Belgique.

Malaise, M. (2007). La Diffusion des Cultes Isiaques: Un Problème de Terminologie et de Critique. In Bricault, Versluys and Meybloom, 2007, pp. 19-39.

Mehl, V. (2009). Le temps venu de la maternité. In Bodiou and Mehl, 2009, pp. 193-206.

Morizot, Y. (2010). L'accouchement: un passage dangereux sous la protection d'Artémis. Bulletin de correspondance hellénique, 134, pp. 463-470.

Murray, A.T. (1925). Iliad, Volume II: Books 13-24 by Homer. Cambridge: Loeb.

Mustakallio, K., Hanska, J., Sainio, H.-L. and Vuolanto, V. (eds.) (2005). Hoping for continuity: childhood, education, and death in Antiquity and the Middle Ages. Roma: Institutum Romanum Finlandiae.

Nikoloska, A. and Müskens, S. (eds.) (2015). Romanising Oriental Gods? Religious Transformations in the Balkan Provinces in the Roman period. New finds and novel perspectives. Skopje: Macedonian Academy of Sciences and Arts. 
Pandermalis, D. (1982). Ein neues Helgitum in Dion. Arch囚ologischer Anzeiger, 97, pp. 727735 .

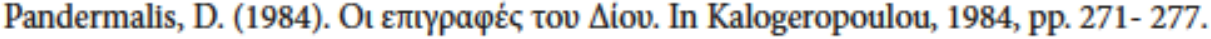

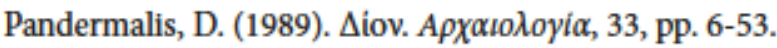

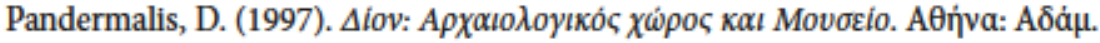

Parker, R. (1983). Miasma. Pollution and purification in early Greek religion. Oxford: Clarendon Press.

Picard, C. (1957). D'Éphèse à la Gaule, et de Stobi (Macédoine) à Clarus. Revue des Études Greques, 70, pp. 108-117.

Pingiatoglou, S. (1981). Eileithyia. Wurzburg: Königshausen and Neumann.

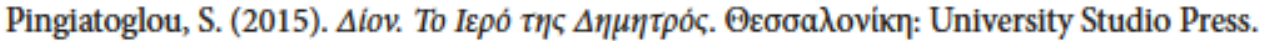

Salviat, Fr. (1959). Décrets pour Épié, fille de Dionysios: déesses et sanctuaires thasien. Bulletin de Correspondance Hellénique, 83, pp. 362-397.

Savvopoulos, K. (2010). Alexandria in Aegypto. The use and meaning of Egyptian elements in Hellenistic and Roman Alexandria. In Bricault and Versluys, 2010, pp. 75- 86.

Showerman, G. (1914). Heroides and Amores by Ovid. London and New York: Loeb.

Steimle, C. (2008). Religion im romischen Thessaloniki: Sakraltopographie, Kult und Gesellschaft 168 v. Chr.-324 n. Chr. Tubingen: Mohr \& Siebeck.

Tataki, A. (1988). Ancient Beroea Prosopography and Society. Athens: Kentron Hellenikes kai Romaikes Archaiotetos.

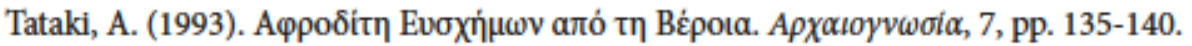

Tran Tam Tinh, V. (1973). Isis Lactans. Corpus des monuments gréco-romains d' Isis allaitant Harpocrate. Leiden: Brill.

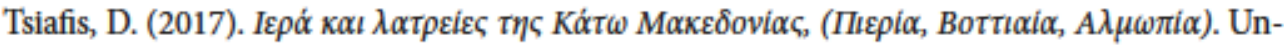
published $\mathrm{PhD}$ thesis, Aristotle University of Thessaloniki.

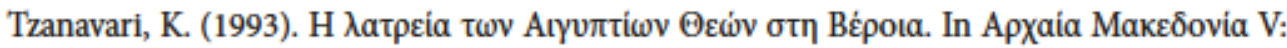

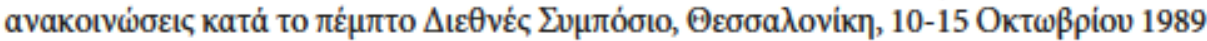

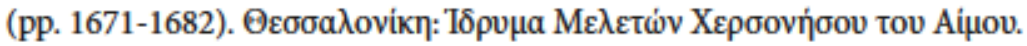

Versnel, H. (1981). Faith, Hope and Worship: Aspects of Religious Mentality in the Ancient World. Leiden: Brill.

Versnel, H. (1990). Ter Unus. Isis, Dionyso, Hermes. Three studies in Henotheism. Leiden: Brill.

Vidman, L. (1969). Sylloge inscriptionum religionis Isiacae et Sarapiacae. Berlin: apud Walter de Gruyter.

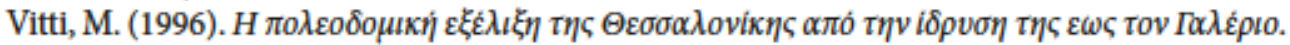

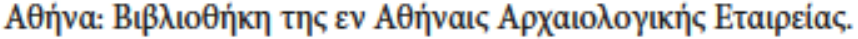

Wild, R. (1981). Water in the Cultic Worship of Isis and Sarapis. Leiden: Brill.

Wild, R. (1984). The Known Isis-Sarapis Sanctuaries from the Roman Period. Aufstieg und Niedergang der römischen Welt, 17.4, pp. 1739-1851.

Wiseman, J. (1973). Gods, War and Plague in the Time of the Antonines. In Wiseman, 1973, pp. 143-184. 
WOMEN AND ISIS LOCHIA: COMMEMORATIONS

OF DIVINE PROTECTION IN ROMAN MACEDONIA

Wiseman, J. (ed.) (1973). Studies in the Antiquities of Stobi I. Beograd: University of Texas at Austin.

Woodward, A. (1912). Inscriptions from Beroea in Macedonia. The Annual of the British School at Athens, 18, pp. 133-165. 